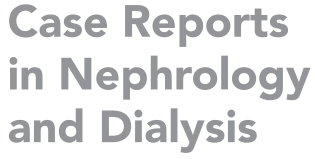

Case Reports and Dialysis

\title{
From Hypokalemic Crisis to Sjogren's Syndrome: A Case Report and Literature Review
}

\author{
Mansour Mbengue $^{\mathrm{a}} \quad$ Cedric Ouanekpone $^{\mathrm{b}} \quad$ Seynabou Diagne ${ }^{\mathrm{c}}$ \\ Abdou Niang ${ }^{\text {a }}$ \\ aDepartment of Nephrology, Dalal Jamm University Hospital, Dakar, Senegal; bepartment \\ of Nephrology, Aristide Le Dantec University Hospital, Dakar, Senegal; 'Department of \\ Nephrology, Pikine Hospital, Dakar, Senegal
}

\section{Keywords}

Tetraparesis · Hypokalemia · Renal tubular acidosis type 1 - Sjögren's syndrome ·

Corticosteroid

\begin{abstract}
Renal involvement occurs in approximately $5 \%$ of patients with Sjögren's syndrome (SS). We reported the case of a 20-year-old African woman who was received for paralysis of 4 limbs secondary to hypokalemia. The diagnosis of renal tubular acidosis type 1 complicated by hypokalemia was retained. In the etiologic research of renal tubular acidosis type 1, primary SS was retained. The patient received symptomatic treatment based on potassium chloride, sodium bicarbonate, hydration, and a low protein diet. In terms of etiological treatment, she was put on corticosteroid and hydroxychloroquine. The outcome was favorable with correction of acidosis and hypokalemia.
\end{abstract}

\section{Introduction}

Renal involvement occurs in approximately 5\% of patients with Sjögren's syndrome (SS) [1]. The disorders described are very heterogeneous according to the studies [1]. Three renal lesions predominate chronic tubulointerstitial nephritis, tubulopathies, and membranoproliferative glomerulonephritis [1]. We report the case of a patient who was presented with distal renal tubular acidosis type 1 (DTA1) secondary to SS, discovered in the context of hypokalemic paralysis. We then provided an updated review of the pathophysiological mechanisms that may explain the link between DTA1 and SS. 


\section{Case Report}

A 20-year-old African woman was received at Dalal Jamm Hospital for paralysis of 4 limbs. The physical examination showed tetraparesis and arrhythmia on cardiac auscultation. The constants were for blood pressure at 120/80 $\mathrm{mm} \mathrm{Hg}$, pulse at 88 beats/min, temperature at $36.6^{\circ} \mathrm{C}$, weight at $69 \mathrm{~kg}$, and diuresis at $3 \mathrm{~L}$. This patient had a long history of hospitalization in the neurology department for tetraparesis secondary to the hypokalemic crisis. She had no family history of kidney disease or sickle cell disease. The Schirmer test was positive. Laboratory investigations revealed on the serum ionogram: $\mathrm{K}^{+}: 1.4 \mathrm{mmol} / \mathrm{L} ; \mathrm{Na}^{+}$: $134 \mathrm{mmol} / \mathrm{L} ; \mathrm{Cl}^{-}: 113 / \mathrm{mmol} / \mathrm{L}$, on the urine ionogram: $\mathrm{Na}^{+}: 250 \mathrm{mmol} / 24 \mathrm{~h} ; \mathrm{K}^{+}: 53 \mathrm{mmol} / 24$ h; $\mathrm{Cl}^{-}: 254 / \mathrm{mmol} / 24 \mathrm{~h}$, urinary urea at $5.2 \mathrm{~g} / 24$, creatinuria at $139 \mathrm{mg} / \mathrm{L}$, glycemia at 0.99 $\mathrm{g} / \mathrm{L}$, urinary osmolarity at $202.6 \mathrm{mmol} / \mathrm{L}$, plasma osmolarity at $290.3 \mathrm{mmol} / \mathrm{L}$, the transtubular potassium gradient (TTKG) at 5, the magnesemia at $23 \mathrm{mg} / \mathrm{L}$, the alkaline reserves at $15.69 \mathrm{mmol} / \mathrm{L}$, the plasma anion gap at 9.3, the urinary anion gap at 10 and the urine $\mathrm{pH}$ to 7.5 , serum creatinine was at $7 \mathrm{mg} / \mathrm{L}$, calcemia at $90 \mathrm{mg} / \mathrm{L}$, phosphatemia at $25 \mathrm{mg} / \mathrm{L}$, and calciuria at $187 \mathrm{mg} / 24 \mathrm{~h}$. Abdomen X-ray showed nephrocalcinosis (Fig. 1). The diagnosis of DTA1 complicated by hypokalemia was retained. The electrocardiogram showed atrial extrasystoles. In etiologic investigations, the hemogram showed hemoglobin at $12.4 \mathrm{~g} / \mathrm{dL}$, white blood cells at $4,080 / \mathrm{mm}^{3}$, lymphopenia at $900 / \mathrm{mm}^{3}$, and platelets at $371,000 / \mathrm{mm}^{3}$. TSHus was normal; C-reactive protein was negative. Electrophoresis of serum proteins showed polyclonal hypergammaglobulinemia. Anti-nuclear antibodies were positive at 380 with speckled fluorescence. The native anti-DNA antibodies were negative. The anti-SSA was positive. The accessory salivary gland biopsy showed grade 4 lymphocytic sialadenitis from Chisholm and Mason (Fig. 2). We had retained the diagnosis of primary SS because she had a score according to 2016 American College of Rheumatology/European League Against Rheumatism Classification Criteria for Primary SS at 7 (The Schirmer test positive [score $=1$ ], labial salivary gland with focal lymphocytic sialadenitis and focus score of $\geq 1$ foci/ $4 \mathrm{~mm}^{2}$ [score $=3$ ] and anti-SSA/Ro positive [score $=3]$ ), and she had no exclusion criteria. Primary SS was identified as the cause of type 1 renal tubular acidosis. The patient received symptomatic treatment based on potassium chloride, sodium bicarbonate, hydration, a low protein diet, and rich in fruits and vegetables. In terms of etiological treatment, she was put on corticosteroid and hydroxychloroquine. The outcome was favorable with correction of acidosis and hypokalemia.

\section{Discussion}

The collecting tube is the site of final regulation of urinary acid excretion, and the type $\mathrm{A}$ intercalary cells in this segment perform the function of distal $\mathrm{H}^{+}$ion secretion and $\mathrm{HCO}_{3}$ reabsorption. The secretion of $\mathrm{H}^{+}$is effected by the $\mathrm{H}^{+}$-ATPase and $\mathrm{H}^{+}, \mathrm{K}^{+}$-ATPase pumps. The $\mathrm{H}^{+}$-ATPase pump is abundantly expressed in the membrane and the cytoplasmic vesicles of the apical pole of type A intercalary cells. The proton secretion activity is coupled with $\mathrm{HCO}_{3}$ reabsorption activity carried out by the renal isoform of the basolateral $\mathrm{Cl}^{-} / \mathrm{HCO}_{3}$ exchanger also known as $\mathrm{AE} 1$. The $\mathrm{Cl}^{-}$ion which enters the cell through the activity of the AE1 exchanger is recycled via the basolateral $\mathrm{K}^{+}-\mathrm{Cl}^{-}$cotransporter or the $\mathrm{Cl}^{-} \mathrm{ClC}-\mathrm{kb}$ channel. Defective type A intercalary cell function will result in hyperchloremic acidosis with urinary pH unsuitable for acidosis ( $>5.5)$ and insufficient net acid excretion. In normal conditions, alkaline urine $(\mathrm{pH}$ $>$ 7.6) stimulates the secretion of $\mathrm{H}^{+}$, and this gradient is greater than $20 \mathrm{~mm} \mathrm{Hg}$. Hyperchloremic acidosis is associated with hypokalemia, hypercalciuria, bone disease (rickets or osteomalacia), and hypocitraturia. Hypokalemia is explained by stimulation of distal potassium

\section{Karger'}


Case Reports in Nephrology and Dialysis

\begin{tabular}{l|l}
\hline Case Rep Nephrol Dial 2021;11:147-151 \\
\hline DOI: 10.1159/000515588 & $\begin{array}{l}\text { (c) 2021 The Author(s). Published by S. Karger AG, Basel } \\
\text { www.karger.com/cnd }\end{array}$ \\
\hline
\end{tabular}

Mbengue et al.: From Hypokalemic Crisis to Sjogren's Syndrome

Fig. 1. Abdomen X-ray showed nephrocalcinosis.

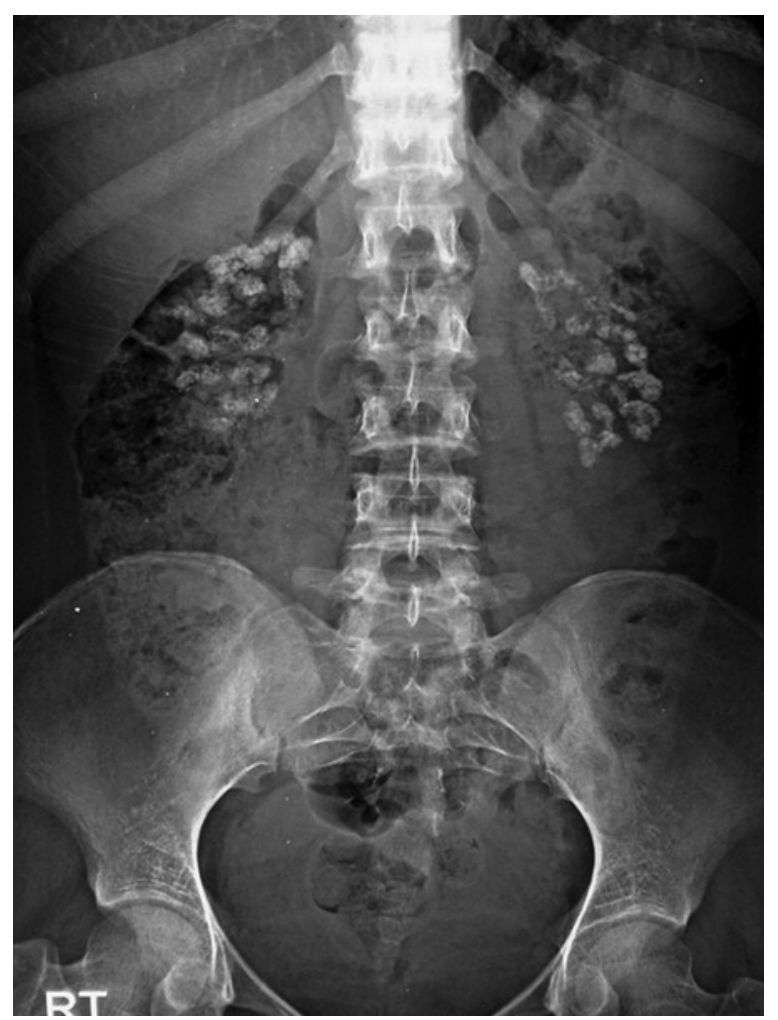

Fig. 2. The accessory salivary gland biopsy showed grade 4 lymphocytic sialadenitis from Chisholm and Mason. HE. $\times 10$.

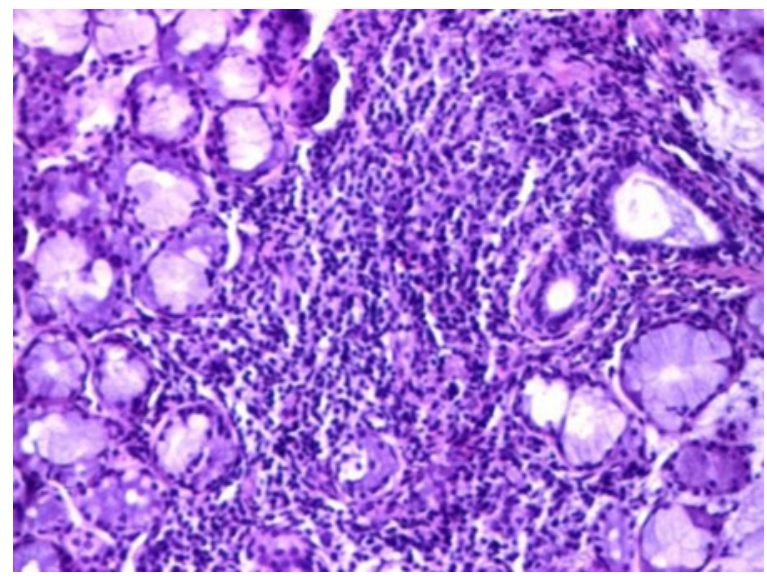

secretion by unreabsorbed bicarbonate and stimulation of the renin-angiotensin-aldosterone system secondary to sodium loss. Chronic acidosis stimulates proximal reabsorption of citrate (1 molecule of citrate produces 3 molecules of bicarbonate) and bone resorption; hypocitraturia, alkaline urine, and hypercalciuria will lead to nephrocalcinosis, and/or nephrolithiasis [2]. The pathogenesis of renal involvement and the pathophysiology of DTA1 during SS are still unclear [3], and probably multifactorial [4].

Kidney disease can be the consequence of tubulointerstitial infiltration of T cells, B cells, and plasma cells and, more rarely, of autoantibodies $[5,6]$. The majority of patients exhibit clinical manifestations that are a direct consequence of interstitial infiltration of lymphocytes, which promotes interstitial fibrosis leading to chronic kidney disease. Tubulitis has also been 
associated with distal DTA and leads to the complete absence of $\mathrm{H}^{+}$-ATPase in the collecting ducts $[6,7]$ and thiazide-sensitive $\mathrm{NaCl}$ cotransporter [5]. Autoantibodies have also been found against $\mathrm{NaCl}$ cotransporter [5] although their precise role in eliciting clinical symptoms remains to be established. Autoantibodies to carbonic anhydrase were found in the serum of patients with lupus erythematosus systemic and SS and were also detected in the renal distal tubules [8]. Autoantibodies to carbonic anhydrase enzymes have been identified in the serum of patients with primary SS [9] and seem to correlate with DTA. Whether these autoantibodies are a consequence of, or contribute to renal injury is not clear, although the induction of antibodies to carbonic anhydrase in mice can reproduce DTA [10]. Some of these autoantibody targets (e.g., carbonic anhydrase II and $\mathrm{H}^{+}$-ATPase) can be found in the salivary glands and in renal intercalated cells [11]. Salivary gland injury, therefore, might cause a release of autoantigens in the kidney, which consequently become the target of both Tlymphocytes and autoantibodies. Moreover, several studies have found a positive correlation between disease duration [12], hypergammaglobulinemia, and the presence of autoantibodies against SSA (Ro) or SSB (La) [13].

The diagnostic delay that is observed in our patient is due to the fact that clinicians are not used to further exploration for hypokalemia and the absence of evident extra-renal signs of SS. The clinical manifestation is also characterized by repetitive episodes of hypokalemic crisis with paralysis of the limbs and which often constitutes a differential diagnosis with Westphal's disease and thyrotoxic hypokalemic paralysis.

Treatment is not codified for DTA1 secondary to SS. It is clear that corticosteroid therapy is not effective on lesions of chronic tubulointerstitial nephropathy. However, DTA1 is mainly attributed at the etiopathogenetic level to immunological phenomena (see above) and not to organic tubulointerstitial involvement. So it makes sense to use corticosteroids during DTA1. If we refer to the literature, we see that corticosteroid therapy has been used in several reported cases but the effectiveness is not established yet [1].

\section{Conclusion}

The pathogenesis of renal involvement and the pathophysiology of DTA1 during SS appear to be related to immunological factors. The use of corticosteroids may be necessary in the management.

\section{Statement of Ethics}

The present case report adhered to the Declaration of Helsinki. Written informed consent for publication was obtained from the patient.

\section{Conflict of Interest Statement}

The authors have no conflicts of interest to declare.

\section{Funding Sources}

This research received no specific grant from any funding agency in the public, commercial, or not-for-profit sectors. 


\section{Case Reports in Nephrology and Dialysis}

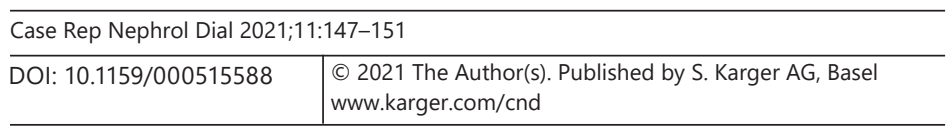

Mbengue et al.: From Hypokalemic Crisis to Sjogren's Syndrome

\section{Author Contributions}

Mansour Mbengue reviewed the literature and wrote the first draft of the manuscript. All authors reviewed and edited the manuscript and approved the final version of the manuscript. Cedric Ouanekpone revised the article critically for important intellectual content. Seynabou Diagne revised the article critically for important intellectual content and gave final approval of the version to be submitted. Abdou Niang revised the article critically for important intellectual content and gave final approval of the version to be submitted.

\section{References}

1 Francois H, Mariette X. Renal involvement in primary Sjogren syndrome. Nat Rev Nephrol. 2015.

2 Thervet E. Traité de néphrologie. Paris: Lavoisier; 2017.

3 Karras D, Antoniadis C, Papadakis J, Variadis S. Quadriplégie flasque aigue revelatrice d'un syndrome de Sjogren avec acidose tubulaire rénale, néphrocalcinose et ostéomalacie. Rev Rhum. 1989;56(6):491-4.

4 Aerts J, Vigouroux C, Fournier P, Cariou D, Pasquier P. Ostéomalacie d'origine rénale révélatrice d'un syndrome de Gougerot-Sjögren. Rev Méd Interne. 1994;15(1):43-7.

5 Kim YK, Song HC, Kim WY, Yoon HE, Choi YJ, Ki CS, et al. Acquired Gitelman syndrome in a patient with primary Sjögren syndrome. Am J Kidney Dis. 2008;52:1163-7.

6 Cohen EP, Bastani B, Cohen MR, Kolner S, Hemken P, Gluck SL. Absence of H(+)-ATPase in cortical collecting tubules of a patient with Sjogren's syndrome and distal renal tubular acidosis. J Am Soc Nephrol. 1992;3: 264-71.

7 DeFranco PE, Haragsim L, Schmitz PG, Bastani B. Absence of vacuolar H(+)-ATPase pump in the collecting duct of a patient with hypokalemic distal renal tubular acidosis and Sjögren's syndrome. J Am Soc Nephrol. 1995; 6:295-301.

8 Inagaki Y, Jinno-Yoshida Y, Hamasaki Y, Ueki H. A novel autoantibody reactive with carbonic anhydrase in sera from patients with systemic lupus erythematosus and Sjögren's syndrome. J Dermatol Sci. 1991;2:147-54.

9 Pertovaara M, Bootorabi F, Kuuslahti M, Pasternack A, Parkkila S. Novel carbonic anhydrase autoantibodies and renal manifestations in patients with primary Sjogren's syndrome. Rheumatology. 2011;50:1453-7.

10 Takemoto F, Katori H, Sawa N, Hoshino J, Suwabe T, Sogawa Y, et al. Induction of anti-carbonic-anhydrase-II antibody causes renal tubular acidosis in a mouse model of Sjogren's syndrome. Nephron Physiol. 2007;106: p63-8.

11 Kim J, Tisher CC, Linser PJ, Madsen KM. Ultrastructural localization of carbonic anhydrase II in subpopulations of intercalated cells of the rat kidney. J Am Soc Nephrol. 1990;1:245-56.

12 Pertovaara M, Korpela M, Kouri T, Pasternack A. The occurrence of renal involvement in primary Sjögren's syndrome: a study of 78 patients. Rheumatology. 1999;38:1113-20.

13 Aasarød K, Haga HJ, Berg KJ, Hammerstrøm J, Jørstad S. Renal involvement in primary Sjögren's syndrome. QJM. 2000; 93:297-304. 